\title{
Synthesis of spiro[dihydropyridine-oxindoles] via three-component reaction of arylamine, isatin and cyclopentane-1,3-dione
}

\author{
Yan Sun, Jing Sun and Chao-Guo Yan*
}

Open Access

\author{
Full Research Paper \\ Address: \\ College of Chemistry \& Chemical Engineering, Yangzhou University, \\ Yangzhou 225002, China \\ Email: \\ Chao-Guo Yan* - cgyan@yzu.edu.cn \\ * Corresponding author \\ Keywords: \\ arylamine; cyclopentanedione; isatin; multicomponent reaction; spiro \\ compound
}

\author{
Beilstein J. Org. Chem. 2013, 9, 8-14. \\ doi:10.3762/bjoc.9.2 \\ Received: 10 October 2012 \\ Accepted: 03 December 2012 \\ Published: 03 January 2013 \\ Associate Editor: T. J. J. Müller \\ (c) 2013 Sun et al; licensee Beilstein-Institut. \\ License and terms: see end of document.
}

\begin{abstract}
A fast and convenient protocol for the synthesis of novel spiro[dihydropyridine-oxindole] derivatives in satisfactory yields was developed by the three-component reactions of arylamine, isatin and cyclopentane-1,3-dione in acetic acid at room temperature. On the other hand the condensation of isatin with two equivalents of cyclopentane-1,3-dione gave 3,3-bis(2-hydroxy-5-oxo-cyclopent1-enyl)oxindole in high yields. The reaction mechanism and substrate scope of this novel reaction is briefly discussed.
\end{abstract}

\section{Introduction}

The spirooxindole is among the most important class of naturally occurring substances, characterized by highly pronounced biological properties, and is also the core structure of many synthetic pharmaceuticals [1,2]. The various biological activities of spirooxindole derivatives have attracted much attention from organic chemists, and as a consequence, a number of methods have been reported for the preparation of spirooxindole-fused heterocycles [3-6]. Isatin and its derivatives may be the most useful starting materials or precursors in the synthesis of a wide number of spirocyclic oxindoles [7,8]. Due to its simple process, easy operation, efficiency and high atomic economy, the multicomponent reaction based on isatin and its derivatives have become an efficient method for the synthesis of various spirooxindoles in recent years $[9,10]$. It is known that the multi- component reactions of isatins with in situ formed azomethine ylides have become the efficient synthetic procedure for constructing versatile spirooxindole systems [11-14]. Considering the above reports, and as part of our program aimed at developing new multicomponent reactions for the construction of complex heterocyclic compounds, we wish in this work to report the efficient synthesis of unprecedented cyclopentylfused spiro[dihydropyridine-oxindoles] by the three-component reaction of arylamine, isatin and cyclopentane-1,3-dione.

\section{Results and Discussion}

Recently we found that the four-component reactions of arylamine, acetylenedicarboxylate, isatin and dimedone in acetic acid resulted in the novel functionalized tetra- 
hydrospiro[indoline-3, 2' -quinoline] derivatives in moderate yields (Scheme 1a) [15]. In order to explore the generality of this four-component reaction, the reactivity of the other cyclic 1,3-diketones was also investigated. In an exploratory experiment, the four-component reaction of $p$-methoxyaniline, dimethyl acetylenedicarboxylate, 1-benzyl-5-methylisatin and cyclopentane-1,3-dione in acetic acid was carried out at room temperature. After workup, we were a little surprised to find that there was no unit of acetylenedicarboxylate in the obtained product (Scheme $1 \mathrm{~b}$ ). In another experiment, the three-component reaction of isatin, cyclopentane-1,3-dione and $\beta$-enamino ester, which was prepared in situ from the addition of $p$-methoxyaniline to dimethyl acetylenedicarboxylate in acetic acid according to our previously established procedure [15], also gave this new kind of spiro product in nearly the same yield. This result clearly indicated that the three-component reaction of arylamine, isatin and clopentane-1,3-dione gave the final spiro product, while the acetylenedicarboxylate could not take part in the reaction.

Attention was therefore turned to evaluate the generality of the three-component reaction of arylamine, isatin and cyclopentane-1,3-dione. Under similar conditions various arylamines and isatins with different substituents reacted with cyclopentane1,3-dione in acetic acid at room temperature for 8-10 hours to afford the corresponding spiro[dihydropyridine-oxindole] compounds $1 \mathbf{a}-1 \mathbf{k}$ in good yields. The results are shown in Table 1. From these results we could see that only anilines with electrondonating alkyl and alkoxy groups reacted smoothly. When anilines with electron-withdrawing $p$-chloro, $p$-bromo, $m$-nitro, or $p$-nitro groups were used in this three-component reaction, no expected spiro[dihydropyridine-oxindole] could be separated from the reaction system. On the other hand, the reaction of $\alpha$-naphthylamine also gave good yields of spiro compound $\mathbf{1 l}$ (Table 1, entry 12).
The structures of spiro compounds $\mathbf{1 a}-\mathbf{1 l}$ were fully characterized by ${ }^{1} \mathrm{H}$ and ${ }^{13} \mathrm{C}$ NMR, HRMS, and IR spectra and were further confirmed by a single-crystal X-ray diffraction study performed for the compound $\mathbf{1 b}$ (Figure 1).

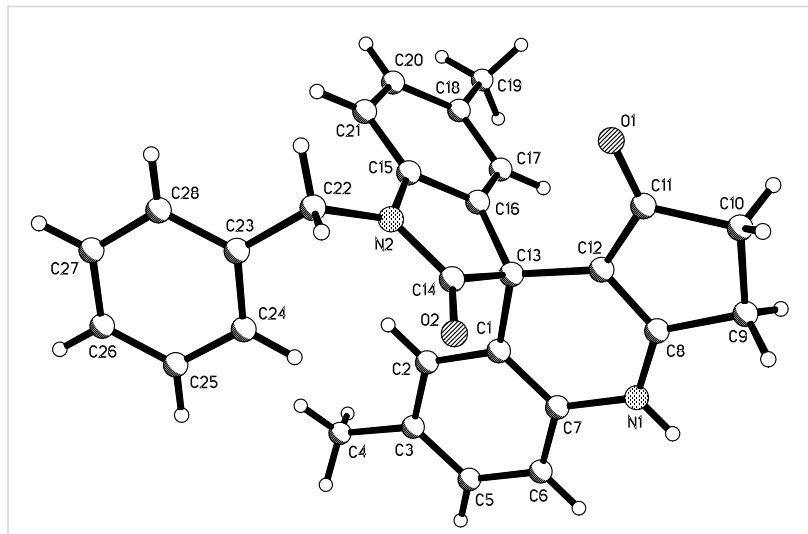

Figure 1: Molecular structure of spiro[dihydropyridine-oxindole] 1b.

It should be pointed out that the structure of the obtained spiro compounds is very interesting, in which the oxindole was connected to the ortho-position of the amino group of arylamine. It is well known that the one-pot reactions of arylamine, isatin and cyclic 1,3-ketone under different catalytic conditions usually gave a kind of spiro[pyridine-oxindole] (I in Figure 2) as the main product, in which the arylamine only provided the amino group to form the pyridyl ring [16-21]. There are only very few papers describing that either 2-naphthylamine [22-25], functionalized 5-aminopyrazoles [26-28], or 2-aminobenzothiazoles [29] reacted with isatin and cyclic 1,3dicarbonyl compounds to give the similar spiro[dihydropyridine-oxindole] (II, III in Figure 2), in which both the amino group and the aryl ring were involved in the construction of the pyridyl ring. In these cases only some special amines such as (a)<smiles>[R]OCC#CC(=O)O[R]</smiles>

(b)<smiles>COc1ccc(N)cc1</smiles>

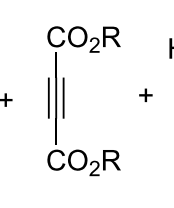<smiles>[R]c1ccc2c(c1)C(=O)C(=O)N2[Z7]</smiles><smiles>[CH2+]C1(C)CC(=O)CC(=O)C1</smiles>

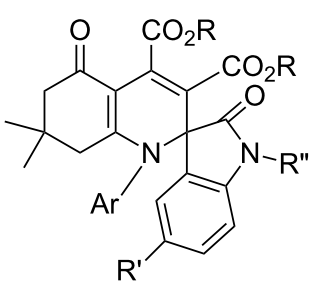


Table 1: Synthesis of spiro[dihydropyridine-oxindole] from three-component reactions.

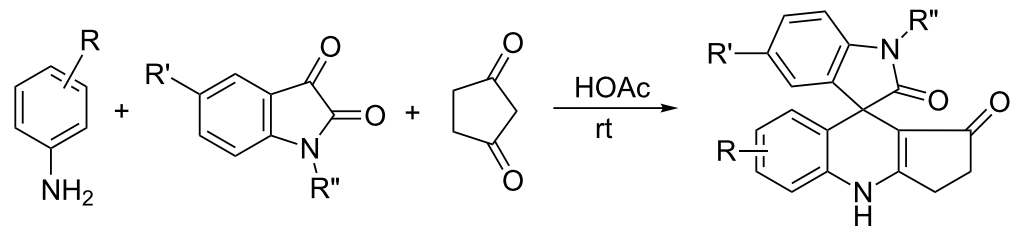

$1 a-11$

\begin{tabular}{|c|c|c|c|c|c|}
\hline Entry & Compound & $\mathrm{R}$ & $\mathrm{R}^{\prime}$ & R" & Yield (\%) \\
\hline 1 & $1 \mathrm{a}$ & $p-\mathrm{CH}_{3} \mathrm{O}$ & $\mathrm{CH}_{3}$ & $\mathrm{CH}_{2} \mathrm{Ph}$ & 88 \\
\hline 2 & $1 b$ & $p-\mathrm{CH}_{3}$ & $\mathrm{CH}_{3}$ & $\mathrm{CH}_{2} \mathrm{Ph}$ & 85 \\
\hline 3 & $1 c$ & $p-\mathrm{CH}_{3} \mathrm{CH}_{2} \mathrm{O}$ & $\mathrm{CH}_{3}$ & $\mathrm{CH}_{2} \mathrm{Ph}$ & 60 \\
\hline 4 & $1 d$ & $p-\left(\mathrm{CH}_{3}\right)_{2} \mathrm{CH}$ & $\mathrm{CH}_{3}$ & $\mathrm{CH}_{2} \mathrm{Ph}$ & 60 \\
\hline 5 & $1 e$ & $p-\left(\mathrm{CH}_{3}\right)_{3} \mathrm{C}$ & $\mathrm{CH}_{3}$ & $\mathrm{CH}_{2} \mathrm{Ph}$ & 65 \\
\hline 6 & $1 f$ & $p-\mathrm{CH}_{3}$ & $\mathrm{H}$ & $\mathrm{CH}_{2} \mathrm{Ph}$ & 74 \\
\hline 7 & $1 \mathrm{~g}$ & $p-\mathrm{CH}_{3} \mathrm{O}$ & $\mathrm{Cl}$ & $n-\mathrm{C}_{4} \mathrm{H}_{9}$ & 52 \\
\hline 8 & $1 \mathrm{~h}$ & $p-\mathrm{CH}_{3}$ & $\mathrm{CH}_{3}$ & $n-\mathrm{C}_{4} \mathrm{H}_{9}$ & 82 \\
\hline 9 & $1 \mathrm{i}$ & $p-\mathrm{CH}_{3}$ & $\mathrm{Cl}$ & $n-\mathrm{C}_{4} \mathrm{H}_{9}$ & 56 \\
\hline 10 & $1 \mathrm{j}$ & $p-\mathrm{CH}_{3}$ & $\mathrm{~F}$ & $n-\mathrm{C}_{4} \mathrm{H}_{9}$ & 58 \\
\hline 11 & $1 \mathrm{k}$ & $p-\mathrm{OH}$ & $\mathrm{CH}_{3}$ & $n-\mathrm{C}_{4} \mathrm{H}_{9}$ & 79 \\
\hline 12 & 11 & a-naphthyl & $\mathrm{CH}_{3}$ & $\mathrm{CH}_{2} \mathrm{Ph}$ & 67 \\
\hline
\end{tabular}<smiles>O=C1CCCC2=C1C1(C(=O)Nc3ccccc31)C1=C(CCCC1=O)N2C1CCCCC1</smiles>

I<smiles>O=C1C(=O)c2c([nH]c3ccc4ccccc4c23)-c2ccccc21</smiles>

II<smiles>O=C1Nc2ccccc2C12C(=O)Nc1[nH]c(=O)[nH]c(=O)c1C2=NN=Cc1ccccc1</smiles>

III

Figure 2: The two kinds of spiro compounds from reactions of isatins with arylamines and cyclic 1,3-diketones.

naphthylamine or heterocyclic amines were employed. It is well known that the reactivity at the $\alpha$-position of 2-naphthylamine and the heterocyclic amine is much higher than that at the ortho-position of aniline. To the best of our knowledge, this new reaction provided the first example of normally substituted aniline showing this kind of reaction pattern.

Encouraged by this success, we extended this three-component reaction to other isatins. When isatins without $N$-substituent were used under similar conditions, the reaction successfully resulted in the expected spiro[dihydropyridine-oxindole] $\mathbf{2 a - 2 g}$ in lower yields (Table 2) and byproducts 3a-3d, which obviously came from the condensation of isatins with two molar cyclopentane-1,3-diones. It is mentioned in Table 1 that isatins with an $\mathrm{N}$-substituent afforded solely spiro[dihydropyridineoxindole] $\mathbf{1 a}-\mathbf{1 l}$ in satisfactory yields. Trying to increase the yields of spiro compounds and decrease the yields of condensation products was not successful. Both the spiro compounds $\mathbf{2 a}-\mathbf{2 g}$ and condensation products $\mathbf{3 a}-\mathbf{3 d}$ have low solubility in common organic solvents, such as chloroform, ethanol and THF, and could be partially dissolved in DMF. The structures of them were successfully established by spectroscopic methods and single crystal determination of compound $\mathbf{2 f}$ (Figure 3 ).

A literature survey showed that even though there are a lot of reports about the condensation of isatins with cyclic 1,3-dicarbonyl compounds [30-33], the condensation reaction of isatin with cyclopentane-1,3-dione seemed still not to have been investigated and the 3,3-bis(2-hydroxy-5-oxo-cyclopent-1enyl)oxindoles 3a-3d have not been prepared until now. Thus, the direct condensation of isatins with two molar cyclopentane1,3-dione was carried out in acetic acid and the desired conden- 
Table 2: Synthesis of spiro[dihydropyridine-oxindole] from three-component reactions.<smiles>[R]c1cccc(N)c1</smiles><smiles>[R]Cc1ccccc1C12NC(CCC(=O)[O-])=C1c1cc([R])ccc1NC2=O</smiles>

2<smiles>[R]c1ccc2c(c1)C(C1=C(O)CCC1=O)(C1=C(O)CCC1=O)C(=O)N2</smiles>

3

\begin{tabular}{|c|c|c|c|c|c|c|}
\hline Entry & $\mathrm{R}$ & $\mathrm{R}^{\prime}$ & Compound 2 & Yield (\%) & Compound $\mathbf{3}$ & Yield (\%) \\
\hline 1 & $p-\mathrm{CH}_{3} \mathrm{O}$ & $\mathrm{H}$ & $2 a$ & 35 & $3 a$ & 20 \\
\hline 2 & $p-\mathrm{CH}_{3} \mathrm{O}$ & $\mathrm{CH}_{3}$ & $2 b$ & 36 & $3 b$ & 18 \\
\hline 3 & $p-\mathrm{CH}_{3} \mathrm{O}$ & $\mathrm{Cl}$ & $2 c$ & 35 & $3 c$ & 16 \\
\hline 4 & $p-\mathrm{CH}_{3} \mathrm{O}$ & $\mathrm{F}$ & $2 d$ & 30 & $3 d$ & 23 \\
\hline 5 & $p-\mathrm{CH}_{3}$ & $\mathrm{H}$ & $2 e$ & 26 & $3 a$ & 25 \\
\hline 6 & $p-\mathrm{CH}_{3}$ & $\mathrm{CH}_{3}$ & $2 f$ & 35 & $3 b$ & 15 \\
\hline 7 & $p-\mathrm{CH}_{3}$ & $\mathrm{Cl}$ & $2 g$ & 32 & $3 c$ & 20 \\
\hline
\end{tabular}

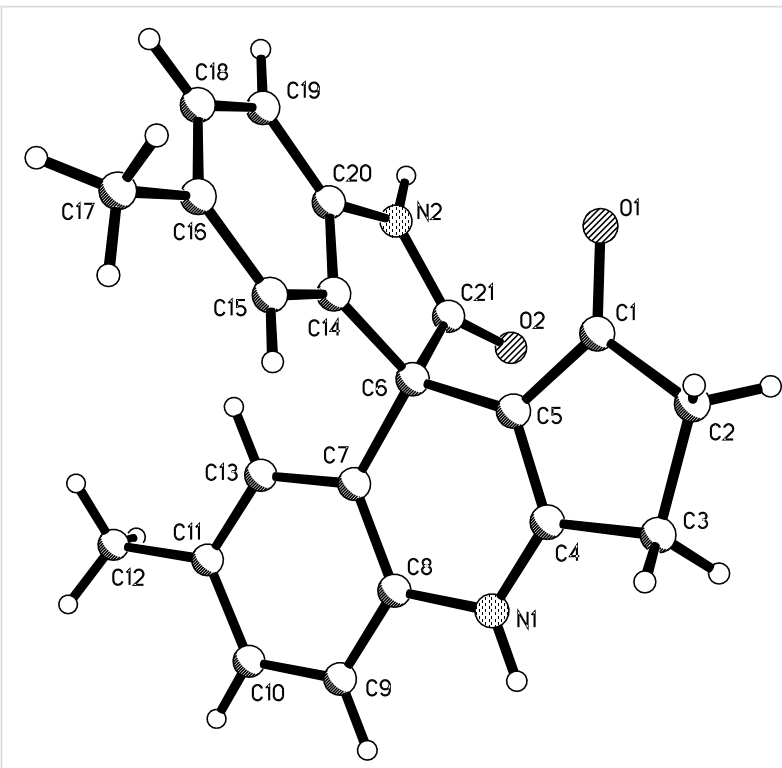

Figure 3: Molecular structure of spiro[dihydropyridine-oxindole] $\mathbf{2 f}$. sation products $\mathbf{3 a}-\mathbf{3 d}$ were obtained in high yields (Scheme 2). Then full characterization data were provided for them, and the single-crystal structure of compound 3d was determined (Figure 4). ${ }^{1} \mathrm{H}$ NMR spectra of 3,3-bis(2-hydroxy-5-oxocyclopent-1-enyl)oxindoles $\mathbf{3 a}-\mathbf{3 d}$ showed a broad signal of two hydroxy groups at about $11.55 \mathrm{ppm}$, which clearly indicates cyclopentane-1,3-dione units exist in enol form. In the crystal structure of $\mathbf{3 d}$ it is clearly seen that there is one carbon$\mathrm{yl}$ group and one enol group in each cyclopentane-1,3-dione moiety.

Although at present the exact mechanism of this three-component reaction is not very clear, a plausible reaction mechanism for the formation of spiro[dihydropyridine-oxindoles] is presented based on the similar multicomponent reactions of isatins [22-29]. Firstly, the reaction of isatin with one equivalent of cyclopentane-1,3-dione in acetic acid forms an aldol adduct (A in Scheme 3). Secondly, a carbonium ion intermediate $\mathbf{B}$ was formed by acidic dehydration of adduct $\mathbf{A}$. Then<smiles>[R]c1ccc2c(c1)C(=O)C(=O)N2C(=O)C1(C2=C(O)CCC2=O)C(=O)Nc2ccc([R])cc21</smiles>

3a: $R^{\prime}=H, 76 \% ; \quad 3 b: R^{\prime}=\mathrm{CH}_{3}, 80 \%$

3c: $R^{\prime}=\mathrm{Cl}, 86 \% ; 3 \mathbf{d}: \mathrm{R}^{\prime}=\mathrm{F}, 83 \%$ 


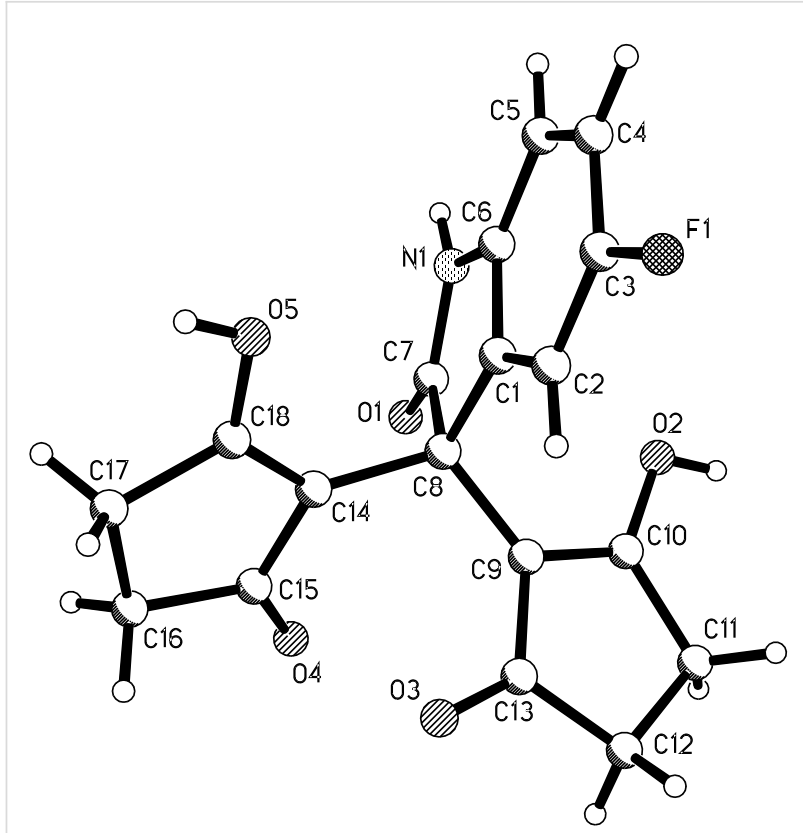

Figure 4: Molecular structure of compound 3d

further reaction of carbonium ion $\mathbf{B}$ with a second equivalent of cyclopentane-1,3-dione gave the double condensation product 3. On the other hand the carbonyl ion $\mathbf{B}$ reacted with the arylamine to give intermediate $\mathbf{C}$. Then the intramolecular dehydration of $\mathbf{C}$ resulted in the final spiro compound $\mathbf{1}$ or $\mathbf{2}$. In this reaction process the reactivity of arylamine played an important factor. The inactive arylamine bearing electron-withdrawing groups could not react with carbonium ion $\mathbf{B}$, thus could not give the expected spiro compound.

\section{Conclusion}

In conclusion, we have described a one-pot three-component reaction of arylamine, isatin and cyclopentane-1,3-dione and found an efficient procedure for the synthesis of a new type of polysubstituted spiro[dihydropyridine-oxindoles]. The reaction mechanism and substrate scope of this novel reaction were briefly discussed. Prominent among the advantages of this new method are operational simplicity, good yields of products in short reaction times, and easy workup procedures. Further expansion of the reaction scope and synthetic applications of this methodology are in progress in our laboratory.

\section{Experimental}

Reagents and apparatus: All reagents and solvents were commercially available with analytical grade and used as received. Evaporative removal of organic solvents was carried out with a rotary evaporator in conjunction with a water jet pump. Melting points were taken on a hot-plate microscope apparatus and were uncorrected. ${ }^{1} \mathrm{H}$ and ${ }^{13} \mathrm{C}$ NMR spectra were recorded on a Bruker AV-600 instrument. IR spectra were obtained on a Bruker Tensor27 spectrometer ( $\mathrm{KBr}$ disc). HRMS were measured on an AB 5800 MALDI-TOF/TOF instrument. X-ray data were collected on a Bruker Smart APEX-2 diffractometer.

Typical procedure for the synthesis of spiro[dihydropyridine-oxindoles] 1a-1l from the three-component reaction of arylamine, cyclopentane-1,3-dione and isatin: A mixture of arylamine $(2.0 \mathrm{mmol})$, isatin $(2.0 \mathrm{mmol})$ and cyclopentane-1,3dione $(2.0 \mathrm{mmol}, 0.196 \mathrm{~g})$ in $10.0 \mathrm{~mL}$ acetic acid was stirred at room temperature for about 9-12 hours. The resulting precipi-<smiles>O=C1CC(=O)CC(C(=O)O)C1</smiles><smiles>O=C1CCC(O)=C1C1(O)C(=O)Nc2ccccc21</smiles>

A<smiles></smiles>

B<smiles>Nc1ccccc1CCC(=O)C1CC2CCC1C2</smiles><smiles>O=C1CCC2=C1C1(C(=O)Nc3ccccc31)c1ccccc1N2</smiles>

1 or 2<smiles>CCOC=O</smiles><smiles>Nc1ccccc1C1(C2=C(O)CCC2=O)C(=O)Nc2ccccc21</smiles>

C 
tates were collected by filtration and washed with cold ethanol to give pure product for analysis. 1a: white solid, $88 \%$; $\mathrm{mp}$ $>300{ }^{\circ} \mathrm{C} ;{ }^{1} \mathrm{H}$ NMR $\left(600 \mathrm{MHz}, \mathrm{DMSO}-d_{6}\right) \delta 10.29(\mathrm{~s}, 1 \mathrm{H}, \mathrm{NH})$, $7.51(\mathrm{~d}, J=7.8 \mathrm{~Hz}, 2 \mathrm{H}, \mathrm{ArH}), 7.33$ (t, $J=7.8 \mathrm{~Hz}, 2 \mathrm{H}, \mathrm{ArH})$ $7.27(\mathrm{~d}, J=7.2 \mathrm{~Hz}, 1 \mathrm{H}, \mathrm{ArH}), 7.00(\mathrm{~d}, J=8.4 \mathrm{~Hz}, 1 \mathrm{H}, \mathrm{ArH})$ $6.94(\mathrm{~d}, J=7.8 \mathrm{~Hz}, 1 \mathrm{H}, \mathrm{ArH}), 6.84-6.82(\mathrm{~m}, 1 \mathrm{H}, \mathrm{ArH}), 6.75(\mathrm{~d}$ $J=7.8 \mathrm{~Hz}, 1 \mathrm{H}, \mathrm{ArH}), 6.70$ (brs, $1 \mathrm{H}, \mathrm{ArH}), 5.90$ (d, $J=8.4 \mathrm{~Hz}$, $1 \mathrm{H}, \mathrm{ArH}), 4.99-4.91\left(\mathrm{~m}, 2 \mathrm{H}, \mathrm{CH}_{2}\right), 3.47\left(\mathrm{~s}, 3 \mathrm{H}, \mathrm{OCH}_{3}\right)$, 2.78-2.77 (m, 2H, $\left.\mathrm{CH}_{2}\right), 2.26-2.25\left(\mathrm{~m}, 2 \mathrm{H}, \mathrm{CH}_{2}\right), 2.13(\mathrm{~s}, 3 \mathrm{H}$, $\left.\mathrm{CH}_{3}\right) ;{ }^{13} \mathrm{C}$ NMR $\left(150 \mathrm{MHz}, \mathrm{DMSO}-d_{6}\right) \delta 198.3,177.6,165.9$, 155.4, 139.5, 137.1, 136.6, 131.6, 130.3, 128.4, 128.1, 127.3, $127.2,124.5,124.4,117.6,113.9,112.5,108.6,108.0,56.0$, $55.1,50.5,43.1,32.8,24.3,20.5,18.5$; IR (KBr) v: 3237, 3112, 3060, 2917, 1686, 1603, 1540, 1494, 1378, 1336, 1288, 1229, 1161, 1114, 1037, 859, $818 \mathrm{~cm}^{-1}$; HRMS-ESI $(\mathrm{m} / \mathrm{z}):[\mathrm{M}-\mathrm{H}]^{-}$ calcd. for $\mathrm{C}_{28} \mathrm{H}_{23} \mathrm{~N}_{2} \mathrm{O}_{3}$ : 435.1714; found, 435.1711.

Typical procedure for the synthesis of spiro[dihydropyridine-oxindoles] $2 \mathrm{a}-2 \mathrm{~g}$ from three-component reaction of arylamine, cyclopentane-1,3-dione and isatin: A mixture of arylamine $(2.0 \mathrm{mmol})$, isatin $(2.0 \mathrm{mmol})$ and cyclopentane-1,3dione $(2.0 \mathrm{mmol}, 0.196 \mathrm{~g})$ in $10.0 \mathrm{~mL}$ acetic acid was stirred at room temperature for about 9-12 hours. The resulting precipitates were collected by filtration and washed with cold ethanol to give the product. Recrystallization in DMF resulted in pure product for analysis.

2a: white solid, $35 \%$; mp $>300{ }^{\circ} \mathrm{C}$; ${ }^{1} \mathrm{H}$ NMR $(600 \mathrm{MHz}$, $\left.\mathrm{DMSO}_{-} d_{6}\right) \delta 10.41(\mathrm{~s}, 1 \mathrm{H}, \mathrm{NH}), 10.21(\mathrm{~s}, 1 \mathrm{H}, \mathrm{NH}), 7.15-7.13$ (m, 1H, ArH), $6.97(\mathrm{~d}, J=8.4 \mathrm{~Hz}, 1 \mathrm{H}, \mathrm{ArH}), 6.87$ (d, $J=7.8$ $\mathrm{Hz}, 1 \mathrm{H}, \mathrm{ArH}), 6.84-6.82$ (m, 2H, ArH), 6.80 (d, J=6.6 Hz, 1H, ArH), 6.61 (s, 1H, ArH), 5.99 (d, J=3.0 Hz, 1H, ArH), 3.54 (s, $\left.3 \mathrm{H}, \mathrm{OCH}_{3}\right), 2.74-2.72\left(\mathrm{~m}, 2 \mathrm{H}, \mathrm{CH}_{2}\right), 2.22-2.20\left(\mathrm{~m}, 2 \mathrm{H}, \mathrm{CH}_{2}\right)$; ${ }^{13} \mathrm{C}$ NMR (150 MHz, DMSO- $\left.d_{6}\right) \delta 198.2,179.2,165.7,155.3$, $141.4,137.9,130.3,127.7,124.6,123.9,121.8,117.4,113.3$, $112.9,109.2,108.1,55.2,50.9,32.8,24.2$; IR (KBr) v: 3203, 3108, 2966, 2925, 2833, 1703, 1661, 1590, 1538, 1494, 1388, 1330, 1288, 1251, 1194, 1162, 1124, 1039, 911, 857, $805 \mathrm{~cm}^{-1}$; HRMS-ESI $(m / z):[\mathrm{M}-\mathrm{H}]^{-}$calcd. for $\mathrm{C}_{20} \mathrm{H}_{15} \mathrm{~N}_{2} \mathrm{O}_{3}: 331.1088$; found, 331.1088 .

Typical procedure for the synthesis of condensation products 3a-3c from condensation reaction of cyclopentane-1,3dione and isatin: A mixture of isatin $(2.0 \mathrm{mmol})$ and cyclopentane-1,3-dione ( $2.0 \mathrm{mmol}, 0.196 \mathrm{~g})$ in $10.0 \mathrm{~mL}$ acetic acid was stirred at room temperature overnight. Then, a second portion of cyclopentane-1,3-dione ( $2.0 \mathrm{mmol}, 0.196 \mathrm{~g}$ ) was added to the system, and the solution was stirred at room temperature for 12 hours. The resulting precipitates were collected by filtration and washed with cold ethanol to give the pure product for analysis. 3a: white solid, 76\%; mp 239-241 ${ }^{\circ} \mathrm{C} ;{ }^{1} \mathrm{H}$ NMR $(600 \mathrm{MHz}$, DMSO- $\left.d_{6}\right) \delta 11.57$ (brs, 2H, OH), 10.42 (s, 1H, NH), 7.23 (d, $J$ $=6.6 \mathrm{~Hz}, 1 \mathrm{H}, \mathrm{ArH}), 7.02$ (brs, $1 \mathrm{H}, \mathrm{ArH}), 6.75$ (brs, $1 \mathrm{H}, \mathrm{ArH}$ ), $6.68(\mathrm{~d}, J=7.2 \mathrm{~Hz}, 1 \mathrm{H}, \mathrm{ArH}), 2.28$ (brs, $\left.8 \mathrm{H}, \mathrm{CH}_{2}\right) ;{ }^{13} \mathrm{C} \mathrm{NMR}$ $\left(150 \mathrm{MHz}, \mathrm{DMSO}-d_{6}\right) \delta 179.0,141.6,132.7,132.6,126.8$, 126.7, 125.7, 120.6, 112.4, 108.5, 43.3, 30.4, 30.3, 30.2, 30.1, $30.0,29.9,29.8,29.7$; IR (KBr) v: 3196, 2925, 1676, 1612, 1573, 1478, 1435, 1385, 1362, 1306, 1232, 1110, 1069, 1040, $881 \mathrm{~cm}^{-1}$; HRMS-ESI $(\mathrm{m} / z):[\mathrm{M}-\mathrm{H}]^{-}$calcd. for $\mathrm{C}_{18} \mathrm{H}_{14} \mathrm{NO}_{5}$ : 324.0877; found, 324.0874 .

Crystallographic data (CIF) of all new compounds are available free of charge via the Internet. Single crystal data for compound 1b (CCDC 869516), 2f (CCDC 869519) and 3d (CCDC 881763 ) have been deposited in the Cambridge Crystallographic Data Centre. These data can be obtained free of charge via http://www.ccdc.cam.ac.uk./data request/cif

\section{Supporting Information}

\section{Supporting Information File 1}

Spectroscopic and analytical data.

[http://www.beilstein-journals.org/bjoc/content/

supplementary/1860-5397-9-2-S1.pdf]

\section{Acknowledgements}

This work was financially supported by the National Natural Science Foundation of China (Grant No. 21172189) and the Priority Academic Program Development of Jiangsu Higher Education Institutions.

\section{References}

1. Tan, B.; Hernández-Torres, G.; Barbas, C. F., III. J. Am. Chem. Soc. 2011, 133, 12354-12357. doi:10.1021/ja203812h

2. Bazgir, A.; Noroozi Tisseh, Z.; Mirzaei, P. Tetrahedron Lett. 2008, 49, 5165-5168. doi:10.1016/j.tetlet.2008.06.077

3. Jadidi, K.; Ghahremanzadeh, R.; Bazgir, A. Tetrahedron 2009, 65, 2005-2009. doi:10.1016/j.tet.2009.01.013

4. Badillo, J. J.; Arevalo, G. E.; Fettinger, J. C.; Franz, A. K. Org. Lett. 2011, 13, 418-421. doi:10.1021/ol1027305

5. Esmaeili, A. A.; Vesalipoor, H.; Hosseinabadi, R.; Zavareh, A. F.; Naseri, N. A.; Ghiamati, E. A. Tetrahedron Lett. 2011, 52, 4865-4867. doi:10.1016/j.tetlet.2011.07.039

6. Kiruthika, S. E.; Lakshmi, N. V.; Banu, B. R.; Perumal, P. T. Tetrahedron Lett. 2011, 52, 6508-6511. doi:10.1016/j.tetlet.2011.09.119

7. Shanmugam, P.; Viswambharan, B.; Madhavan, S. Org. Lett. 2007, 9, 4095-4098. doi:10.1021/ol701533d

8. Deng, H.-P.; Wei, Y.; Shi, M. Org. Lett. 2011, 13, 3348-3351. doi:10.1021/ol201094f

9. Viswambharan, B.; Selvakumar, K.; Madhavan, S.; Shanmugam, P. Org. Lett. 2010, 12, 2108-2111. doi:10.1021/ol100591r 
10. Quiroga, J.; Portillo, S.; Pérez, A.; Gálvez, J.; Abonia, R.; Insuasty, B. Tetrahedron Lett. 2011, 52, 2664-2666.

doi:10.1016/j.tetlet.2011.03.067

11. Shakibaei, G. I.; Feiz, A.; Khavasi, H. R.; Soorki, A. A.; Bazgir, A. ACS Comb. Sci. 2011, 13, 96-99. doi:10.1021/c01000053

12. Mohammadi, A. A.; Dabiri, M.; Qaraat, H. Tetrahedron 2009, 65, 3804-3808. doi:10.1016/j.tet.2009.02.037

13. Basavaiah, D.; Reddy, K. R. Org. Lett. 2007, 9, 57-60. doi:10.1021/ol062561m

14. Liu, H.; Dou, D.; Shi, D. J. Comb. Chem. 2010, 12, 633-637. doi:10.1021/cc100035q

15. Sun, J.; Sun, Y.; Gao, H.; Yan, C.-G. Eur. J. Org. Chem. 2012, 1976-1983. doi:10.1002/ejoc.201101737

16. Joshi, K. C.; Jain, R.; Arora, S. J. Fluorine Chem. 1989, 42, 149-162. doi:10.1016/S0022-1139(00)82745-1

17. Dabiri, M.; Bahramnejad, M.; Baghbanzadeh, M. Tetrahedron 2009, 65 , 9443-9447. doi:10.1016/j.tet.2009.08.070

18. Ghahremanzadeh, R.; Ahadi, S.; Shakibaei, G. I.; Bazgir, A. Tetrahedron Lett. 2010, 51, 499-502. doi:10.1016/j.tetlet.2009.11.041

19. Ghahremanzadeh, R.; Shakibaei, G. I.; Ahadi, S.; Bazgir, A. J. Comb. Chem. 2010, 12, 191-194. doi:10.1021/cc900130a

20. Jadidi, K.; Ghahremanzadeh, R.; Bazgir, A. J. Comb. Chem. 2009, 11, 341-344. doi:10.1021/cc800167h

21. Kefayati, H.; Narchin, F.; Rad-Moghadam, K. Tetrahedron Lett. 2012, 53, 4573-4575. doi:10.1016/j.tetlet.2012.06.070

22. Ghahremanzadeh, R.; Fereshtehnejad, F.; Bazgir, A. J. Heterocycl. Chem. 2010, 47, 1031-1034. doi:10.1002/jhet.412

23. Rad-Moghadam, K.; Youseftabar-Miri, L. Synlett 2010, 1969-1973. doi:10.1055/s-0030-1258506

24. Lu, G.-P.; Cai, C. J. Chem. Res. 2011, 35, 547-551. doi:10.3184/174751911X13157531279974

25. Rad-Moghadam, K.; Youseftabar-Miri, L. J. Fluorine Chem. 2012, 135, 213-219. doi:10.1016/j.jfluchem.2011.11.007

26. Ghahremanzadeh, R.; Sayyafi, M.; Ahadi, S.; Bazgir, A. J. Comb. Chem. 2009, 11, 393-396. doi:10.1021/cc8001958

27. Bazgir, A.; Ahadi, S.; Ghahremanzadeh, R.; Khavasi, H. R.; Mirzaei, P. Ultrason. Sonochem. 2010, 17, 447-462. doi:10.1016/j.ultsonch.2009.09.009

28. Khorrami, A. R.; Faraji, F.; Bazgir, A. Ultrason. Sonochem. 2010, 17, 587-591. doi:10.1016/j.ultsonch.2009.11.017

29. Arya, K. A.; Kumar, M. Mol. Diversity 2011, 15, 781-789. doi:10.1007/s11030-011-9309-2

30. Stefanović, G.; Pavičić-Woss, M.; Lorenc, L.; Mihailović, M. L. Tetrahedron 1959, 6, 97-102. doi:10.1016/0040-4020(59)85001-8

31. Joshi, K. C.; Jain, R.; Arora, S. Indian J. Heterocycl. Chem. 1991, 1, 95-97.

32. Dabiri, M.; Tisseh, Z. N.; Bahramnejad, M.; Bazgir, A. Ultrason. Sonochem. 2011, 18, 1153-1159. doi:10.1016/j.ultsonch.2010.12.004

33. Ghahremanzadeh, R.; Fereshtehnejad, F.; Mirzaei, P.; Bazgir, A. Ultrason. Sonochem. 2011, 18, 415-418.

doi:10.1016/j.ultsonch.2010.07.010

\section{License and Terms}

This is an Open Access article under the terms of the Creative Commons Attribution License

(http://creativecommons.org/licenses/by/2.0), which permits unrestricted use, distribution, and reproduction in any medium, provided the original work is properly cited.

The license is subject to the Beilstein Journal of Organic Chemistry terms and conditions:

(http://www.beilstein-journals.org/bjoc)

The definitive version of this article is the electronic one which can be found at:

doi:10.3762/bjoc. 9.2 